\title{
Dental caries in preschoolers from communes with fluoridated and non-fluoridated public water supplies in Chile
}

\author{
Cárie dentária em pré-escolares de comunidades com e sem \\ fluoretação de agua no Chile
}

\begin{abstract}
Purpose: To determine the prevalence and severity of dental caries in three- to five-year-old preschool children from two communes in Chile: one with a fluoridated public water supply and the other with a non-fluoridated public water supply.

Methods: Study design: Cross-sectional observational study. The sample was composed of 200 children from three to five years old, with good general health, of low socioeconomic status, attending four kindergarten schools of the Metropolitan Region of Santiago, Chile. Two schools were located in the commune of Maipú, which does not have fluoridated public water, and two schools were located in the commune of Peñalolen, which has had fluoridated public water since 1996, at a fluoride concentration of $0.6 \mathrm{mg} / \mathrm{L}$. The WHO (World Health Organization) methodology was used to measure the percentage of caries-free children, and the $\mathrm{dmft}$ index was used to measure the severity of the disease.

Results: The results showed that $24 \%$ of the children in Maipú were caries free, compared to $55 \%$ in Peñalolen. The dmft index was 3.38 and 1.84 in Maipú and Peñalolen, respectively. These indices increased with age.

Conclusion: The prevalence and severity of dental caries in three- to five-year-old preschoolers were higher in Maipú, the commune with non-fluoridated water, than in Peñalolen, the commune with fluoridated water.
\end{abstract}

Key words: Dental caries; caries-free; dmft index; fluoride; preschool children

\section{Resumo}

Objetivo: Determinar a prevalência e severidade da doença cárie dentária em crianças préescolares de 3 a 5 anos de idade em creches no Chile, localizadas em uma comunidade sem fluoretação da água de abastecimento público e em outra comunidade com agua fluoretada.

Metodologia: Delineamento do estudo: observacional, transversal. A amostra foi composta por 200 crianças de 3 a 5 anos, com boa saúde geral, pertencentes a baixos estratos sociais, de quatro creches da Região Metropolitana de Santiago, dois do município de Maipú sem fluoretação da água de abastecimento público e duas do município de Peñalolén com fluoretação desde 1996, com concentração de flúor de 0,6 mg/L. A metodologia da OMS foi utilizada para o registro da percentagem de crianças livres de cárie e o índice cpod foi usado para medir a severidade da doença.

Resultados: A porcentagem de crianças livres de cárie foi de 24\% em Maipú e 55\% em Peñalolén, com índice cpod de 3,38 e 1,84, respectivamente. Estes resultados aumentaram com a idade.

Conclusão: A prevalência e severidade da cárie dentária em pré-escolares de 3 a 5 anos em Maipú (agua não fluoretada) foram superiores aos observados em Peñalolén (água fluoretada).

Palavras-chave: Cárie dentária; índice cpod; flúor; pré-escolares

\author{
Ismael Yévenes Lopez ${ }^{\circ}$ \\ Barbara Hernández ${ }^{b}$ \\ Alfredo Apip Ramos \\ Miguel Neira Jara a \\ Paula Maass Wolfenson a \\ Ljubica Petrasic Smith b
}

a Department of Chemical Sciences, Dental School,
University of Chile, Santiago, Chile
b Department of Restorative Dentistry, Dental
School, University of Chile, Santiago, Chile

\author{
Correspondence: \\ Ismael Yévenes \\ Department of Chemistry, Dental School \\ University of Chile \\ Sergio Livingstone (ex-Olivos) 943, Independencia \\ Santiago - Chile \\ E-mail: iyevenes@odontologia.uchile.cl
}




\section{Introduction}

Dental caries is an infectious, polymicrobial, localized, progressive, and transmissible disease, which affects the hard tissues of teeth and constitutes a serious public health problem for industrialized and developing countries (1). The most efficient public method to prevent and control dental caries is water fluoridation (2). Fluoride (F-), has the ability to reduce the incidence of dental caries and reverse the progression of incipient lesions. The incorporation of fluoride in drinking water began in 1945 and 1946 in the U.S. and Canada, changing the concentration of this component in four communities $(3,4)$. The implementation of this measure was an important factor in caries decline and its severity, which was also observed in other economically developed countries (1).

In 1986 the WHO (World Health Organization) stated that fluoride modifies the tooth structure and shape and increases the resistance of the enamel, reducing the risk for developing dental caries. At present, many studies support the use of fluoride for preventive and therapeutic purposes $(3,5,6)$. In Chile, water fluoridation has been in implementation stage since 1953, in a continuous way in several parts of the country, and it has been considered a national project since 1984 (7).

Information of dental health in preschool children at a national level in Chile is limited. A report conducted in 2003 on bottle-caries in preschool children between 2 to 4 years old, attending institutions of the board of the National Gardens (JUNJI) of the Santiago Metropolitan Region, found that $33.7 \%$ of children were affected by dental caries (8). More recently, in 2007, the Chilean Health Ministry (MINSAL) conducted a study on oral health of preschool children between 2 to 4 years old in the Santiago Metropolitan Area and found that $83 \%$ of the 2 year-old children did not present a history of dental caries, while at the age of 4 years old, the percentage of caries-free children decreased to $52 \%$ (9).

The purpose of this study was to record the prevalence and severity of dental caries in 3-5 year-old preschool children attending four kindergarten schools in Chile, two of them located in Maipú commune, without F- in the water supply, and two schools located in Peñalolén commune, which has fluoridated water supply since 1996 at a concentration of $0.6 \mathrm{mg} / \mathrm{L}$. It is relevant to mention that both municipalities have a public program to promote oral health for children in the group-age of 3-5 years old, which is based on health education and supervised tooth brushing by their teachers.

\section{Methods}

\section{Study design and sample}

The study design was observational, cross-sectional. The sample was composed by 200 children attending four kindergarten schools belonging to the board of the National Gardens (JUNJI) of the Santiago Metropolitan Region, Chile. Two schools were located in the commune of Maipú and two schools in the commune of Peñalolen. From each kindergarten school, 50 children between 3 and 5 years old were selected. The parents of all children accepted to participate in the study and signed an informed consent form. The inclusion criteria were: children with good general health, residents in the Maipú and Peñalolen communes of the Santiago Metropolitan Region. The exclusion criteria comprised those children who have changed their commune of residence throughout their lives. The CASEN survey (Social Economic Characterization Survey) - 2003, indicated that the target population had low socioeconomic status, with a poverty percentage of $10.5 \%$ for the districts Maipú and $16.7 \%$ for Peñalolen.

Data were collected from a total 100 children residents of the non-fluoridated commune of Maipú $(\mathrm{n}=45 \%, 3$ years-old; $\mathrm{n}=44 \%, 4$ years-old; $11 \%, 5$ years-old) and 100 children living in the fluoridated commune of Peñalolen $(\mathrm{n}=47 \%, 3$ years-old; $\mathrm{n}=45 \% 4$ years-old; $8 \%, 5$ yearsold) (Table 1). For calculation, the age of the children was considered as completed years from the date of the examination, i.e., for a 3 year-old child was considered the age from 3 years and 0 months until 3 years, 11 months and 30 days.

\section{Clinical evaluation}

To record the caries prevalence and the number of cariesfree children, we used the WHO methodology described in the Health Survey Basic Methods, $4^{\text {th }}$ edition, Geneva, 1997, for epidemiological studies (10). The dmft index was used to determine the frequency of decayed (d), filled ( $f$ ) and missing $(\mathrm{m})$ teeth by dental caries in primary teeth.

The examiners were trained by the project advisor in relation to the forms, codes and diagnostic criteria used in the present study. The calibration for caries diagnosis was performed in the kindergarten school "Prof. Dr. Emilio Navarro Morales" of the Jose Joaquin Aguirre Hospital. The statistical calibration study showed Kappa of 0.87 for inter-examiner agreement and 0.93 for intra-examiner agreement.

Table 1. Distribution of the study population by kindergarten schools, commune, age and sex.

\begin{tabular}{llcccccc}
\hline \multirow{2}{*}{ Commune } & \multirow{2}{*}{ Kindergarten School } & \multirow{2}{*}{$\begin{array}{c}\text { Total } \\
\text { (n) }\end{array}$} & \multicolumn{3}{c}{ Age (Years) } & \multicolumn{2}{c}{ Sex (\%) } \\
\cline { 5 - 9 } & & & 3 & 4 & 5 & Male & Female \\
\hline \multirow{3}{*}{ Maipú } & Pequeños Exploradores & 50 & 22 & 24 & 4 & 48 & 52 \\
& Emanuel & 50 & 23 & 20 & 7 & 48 & 52 \\
& Nido de Cóndores & 50 & 23 & 23 & 4 & 54 & 46 \\
& Mundo de Niños & 50 & 24 & 22 & 4 & 44 & 56 \\
& & 200 & 92 & 89 & 19 & 50.5 & 49.5 \\
\hline
\end{tabular}


The oral examination was performed in the classroom, placing the child lying on a desk. The teeth were examined under artificial light and using a clinical mirror. Before clinical examination, the child's oral hygiene was performed with tooth brushing.

Data were analyzed by Statistic 4.5 software (StatSoft, Tulsa, USA) with Student's t-test and analysis of variance at a 0.05 significance level and 95\% confidence interval.

\section{Results}

Table 2 shows that in the commune of Maipu $24 \%$ of the examined children were caries-free. The group of 3 years old and 4 years old showed similar results, $27 \%$ and $25 \%$ caries-free, respectively, while the group of 5 years old had $9 \%$ caries-free subjects.

In Peñalolen a total of 55\% were caries-free. The 3 year-old children had the highest percentage of caries-free (65.9\%), followed by 4 year-old (46.6\%) and 5 year-old children $(37.5 \%)$, with no difference between age groups $(P>0.05)$. Table 3 shows the distribution of caries-free children by age and gender. A clear trend was not observed in the relationship between sex and percentage of caries-free in Maipú $(P>0.05)$. For the 3 and 4 year-old groups in Peñalolen, females showed higher values than males, $74 \%$ and $55 \%$ in the group of 3 year-old and $57.8 \%$ and $38.46 \%$ in 4 year-old children, respectively. For the group of 5 year-old children, $33.3 \%$ of the male children were caries-free while $20 \%$ of the girls had such condition. However, no significant difference in frequency of caries-free subjects was observed regarding sex $(P>0.05)$.

Table 4 describes the history of caries measuring the $\mathrm{dmft}$ index according to age. In Maipú the dmft index was higher in children of 5 years (4.63), followed by the 3 year-old children, with dmft index of 3.37, and then the group of 4 years of age $(\mathrm{dmft}$ index $=3.06)$. The group of 5 years showed the highest rate of decayed teeth (D) $(P<0.05)$, but the average filled teeth $(\mathrm{F})$ and teeth with indication of extraction for caries (M) showed no significant difference between groups. For the commune Peñalolen the lowest $\mathrm{dmft}$ index was observed in 3 year-old children (1.12); groups 4 and 5 years of age had higher dmft values, 2.51 and 2.25, respectively, without statistically significant difference. The highest rate of caries was presented by children 5 years old $(P<0.05)$.

Table 5 shows the dmft index distribution by sex. The difference between girls and boys was higher in Peñalolen than in Maipú, but with no conclusive data. The overall $\mathrm{dmft}$ index was 3.38 for the municipality of Maipú and 1.84 for Peñalolen $(P<0.05)$.

Table 2. Distribution of caries-free children from Maipú and Peñalolen by age.

\begin{tabular}{ccccccc}
\hline \multirow{2}{*}{$\begin{array}{c}\text { Age } \\
\text { (Years) }\end{array}$} & \multicolumn{2}{c}{ Caries-Free Maipú } & \multicolumn{4}{c}{ Caries-Free Peñalolen } \\
\cline { 2 - 7 } & Sample & $\mathbf{n}$ & $\%$ & Sample & $\mathbf{n}$ & $\%$ \\
\hline 3 & 45 & 12 & 26.6 & 47 & 31 & 65.9 \\
4 & 44 & 11 & 25 & 45 & 21 & 46.6 \\
5 & 11 & 1 & 9 & 8 & 3 & 37.5 \\
Total & 100 & 24 & 24 & 100 & 55 & 55 \\
\hline
\end{tabular}

Table 3. Percentage of caries-free children from Maipú and Peñalolen by age and sex.

\begin{tabular}{|c|c|c|c|c|c|c|c|c|c|c|c|c|c|c|c|c|c|c|}
\hline \multirow{3}{*}{ Sex } & \multicolumn{9}{|c|}{ Maipu } & \multicolumn{9}{|c|}{ Peñalolen } \\
\hline & \multicolumn{3}{|c|}{3 years } & \multicolumn{3}{|c|}{4 years } & \multicolumn{3}{|c|}{5 years } & \multicolumn{3}{|c|}{3 years } & \multicolumn{3}{|c|}{4 years } & \multicolumn{3}{|c|}{5 years } \\
\hline & Total & $\mathrm{n}$ & $\%$ & Total & $\mathrm{n}$ & $\%$ & Total & $\mathrm{n}$ & $\%$ & Total & $\mathrm{n}$ & $\%$ & Total & $\mathrm{n}$ & $\%$ & Total & $\mathrm{n}$ & $\%$ \\
\hline Male & 26 & 7 & 26.9 & 18 & 4 & 22.2 & 8 & 1 & 12.5 & 20 & 11 & 55 & 26 & 10 & 38.4 & 3 & 1 & 33.3 \\
\hline Female & 19 & 5 & 26.3 & 26 & 7 & 26.9 & 3 & 0 & 0 & 27 & 20 & 74 & 19 & 11 & 57.8 & 5 & 1 & 20 \\
\hline Total & 45 & 12 & 26.6 & 44 & 11 & 25 & 11 & 1 & 9 & 47 & 31 & 65.9 & 45 & 21 & 46.6 & 8 & 2 & 25 \\
\hline
\end{tabular}

Table 4. History of caries in 3, 4 and 5 year-old children from Maipú and Penalolen. dmft index mean and standard deviation (SD) values.

\begin{tabular}{|c|c|c|c|c|c|c|c|c|c|c|}
\hline \multirow{2}{*}{$\begin{array}{c}\text { Age } \\
\text { years) }\end{array}$} & \multicolumn{5}{|c|}{ Maipú } & \multicolumn{5}{|c|}{ Peñalolen } \\
\hline & $d$ & $\mathrm{~m}$ & $f$ & dmft & SD & $\mathrm{d}$ & $\mathrm{m}$ & $f$ & $\mathrm{dmft}$ & SD \\
\hline 3 & 2.97 & 0.15 & 0.24 & 3.37 & 3.00 & 1.06 & 0 & 0.04 & 1.12 & 2.14 \\
\hline 4 & 2.56 & 0.15 & 0.34 & 3.06 & 2.98 & 1.77 & 0.08 & 0.64 & 2.51 & 2.65 \\
\hline 5 & 4.36 & 0.0 & 0.27 & 4.63 & 3.23 & 1.87 & 0 & 0.37 & 2.25 & 2.31 \\
\hline Total & 3.29 & 0.1 & 0.28 & 3.38 & 3.02 & 1.46 & 0.04 & 0.34 & 1.84 & 2.46 \\
\hline
\end{tabular}

Table 5. Caries history by gender in 3, 4 and 5 year-old children from Maipú and Penalolen. dmft index mean and standard deviation (SD) values.

\begin{tabular}{lcccc}
\hline \multirow{2}{*}{ Sex } & \multicolumn{2}{c}{ Maipú } & \multicolumn{2}{c}{ Peñalolen } \\
\cline { 2 - 5 } & $\mathrm{dmft}$ & $\mathrm{SD}$ & $\mathrm{dmft}$ & $\mathrm{SD}$ \\
\hline Male & 3.42 & 3.23 & 2.53 & 2.85 \\
Famale & 3.33 & 2.82 & 1.17 & 1.87 \\
Total & 3.38 & 3.02 & 1.84 & 2.46 \\
\hline
\end{tabular}




\section{Discussion}

\section{Caries Prevalence}

The presents study showed a significant decrease in the caries indicators compared to previous studies. The study by Urbina et al., Metropolitan Region - 1996, described a prevalence of $12.6 \%$ of caries-free children at 6,8 and 12 years old (11). Subsequently, the survey by the Chilean Health Ministry in 2004-2005 (12), which assessed the impact of water fluoridation in the Santiago metropolitan area, $23.7 \%$ were caries-free for the same age-range of the present study and $24.2 \%$ for $6-8$ year-old children.

The present findings showed that $24 \%$ of the children 3 to 5 years old were caries-free in Maipú (without fluoridated water) and 55\% in Peñalolen (fluoridated since 1996). The frequency of caries-free in Maipú was similar to the results reported by Guerrero et al., in 1997, for a population of the South Santiago metropolitan area, where $25.9 \%$ of the children were caries-free (13). Weason et al., in 2005, reported a history of caries of $80.4 \%$ for children of 4 to 6 years old, in the city of Concepción, also without fluoride in the public water supply (14).

The values recorded in Peñalolen correspond to those described by Fields, in 2009, for a preschool population of the commune of Peñaflor, also fluoridated since 1996, which had $43.2 \%$ caries-free for children 3 to 5 years old and a slight decline in this indicator with increasing age (15). However, similarly to the aforementioned work, the present study does not supply evidence that differences exist between age groups.

Compared to studies in Latin-America, the percentage of children caries-free in Peñalolen was greater than those found in other countries. A study in Brazil, in 2004, showed a high prevalence of dental caries in children of 5 years old $(60 \%)$, which increased in older age groups (16). Also, in Joao Pessoa, Paraíba, Brazil, the presence of caries-free children in the age group of 3-5 years old was $13.9 \%$ (17).

Similarly, a national study realized in Colombia in 2000 to assess the impact of the consumption of fluoridated salt showed $45.2 \%$ caries-free (18). In Cordova, Argentina, whose natural fluoride in the water has concentrations ranging from 0.8 to $1.0 \mathrm{ppm}, 38 \%$ of the examined children were caries-free (19). In Europe, the percentage of children free of caries is lower. In England, 39.4\% of the children aged 5 to 6 years old had a history of caries in dentin (20). An oral health survey in Spain, in 2007, found a prevalence of $17.4 \%$ of caries in preschool children of 3 years old and $26.2 \%$ for those of 4 years old (21). Such differences can be attributed to cultural, social and technical aspects related to the population.

In 2001, James et al. (22) compared the experience of dental caries in non-fluoridated and fluoridated communities over 11 years, in children 5 to 11 years old in the state of Tennessee, USA. That study found that the residents of the fluoridated regions had $42 \%$ caries-free whereas in nonfluoridated this value was $35 \%$ (22). This result is similar to the present findings, where there is a strong difference between children from Maipú (23\% caries-free) and from Peñalolen (55\%). Regarding the distribution of caries-free by sex, the work of 1996 (11) showed in children 6-8 years old that females had a higher value (14\%) than males (11\%). In the same age range, the 2004 study described that $26 \%$ of male children and $23.3 \%$ of girls were caries-free (12). The frequency of caries-free for the total sample of the present study was $44 \%$ of girls and $34 \%$ of boys, but there was no background to establish a significant relationship.

\section{Caries Severity}

The history and severity of dental caries were quantified by the $\mathrm{dmft}$ index. The municipality of Maipú showed a dmft index of 3.38 for children 3 to 5 years old, which is a lower value than described by Urbina in 1996 (11) for children 6 to 8 years old (4.29) in the metropolitan area when the program of fluoridation of the public water supply was not yet implemented, and lower than the dmft 4.8 described by Weason, in Concepción, in 2005 (14). However, these figures are higher than that found in Joao Pessoa, Brazil (dmft 2.38), where no fluoridated public water supply was available (17). In Maipú the breakdown of the $\mathrm{dmft}$ index yielded a value of 3.29 for the component "d", 0.15 for " $\mathrm{m}$ " and 0.28 for " $\mathrm{f}$ ", i.e., the strong contribution to the overall $\mathrm{dmft}$ index was by caries and the lowest contribution was from the filled teeth component. This may be due to the exclusion of the population of 3 to 5 years old in the current public dental care program, named the AUGE program, which ensures the care of children between 6 and 12 years of age.

The results for the commune of Peñalolen are slightly lower for the history and caries severity than that described by Campos (15) for Peñaflor ( $\mathrm{dmft}$ index=2.11). In the present study, the total dmft index was 1.84 for the 3-5 years old children, but the proportion of "d" was 1.46 , "m" was 0.04 , and "f" was 0.34 , which were equivalent to the values described by Campos $(\mathrm{d}=1.84, \mathrm{~m}=0.06$ and $\mathrm{f}=0.21)$.

Compared with international studies, these reports are similar to those found by Montero et al., in Venezuela, in 2007 (23). Conversely, in Campeche, Mexico, teenagers between 13 and 16 years old had an average DMFT index of 7.3 (24). These differences can be due to the fact that history and severity of dental caries increases with age of the child, because of the increased exposure to risk factors. The distribution of the history and severity of caries by sex in Maipú and Peñalolen showed that the $\mathrm{dmft}$ index values were lower in girls than in boys. However, there was no significant statistical evidence to establish a relationship. The study by Campos (15) and the MINSAL work in 2004 showed similar results (12).

\section{Conclusions}

The prevalence and severity of dental caries in 3 to 5 yearold children from the non-fluoridated commune of Maipú were higher than in children from the fluoridated commune of Peñalolen. 


\section{References}

1. Bratthall D, Hansel Petersson G, Sundberg H. Reasons for the caries decline: what do the experts believe? Eur J Oral Sci 1996;104: 416-22.

2. Narvai PC. Dental caries and fluorine: a twentieth century relation. Cienc Saúde Coletiva 2000;5:381-92.

3. Ast DB, Finn SB, McCaffrey I. The Newburgh-Kingston caries fluorine study I. Dental findings after three years of water fluoridation. Am J Public Health 1950;40:716-24.

4. Dean HT, Arnold FA Jr, Jay P, Knutson JW. Studies on mass control of dental caries through fluoridation of the public water supply. Public Health Rep 1950;65:1403-8.

5. World Health Organization. Fluorides and oral dental health. Report of Expert Committee N.846. Genebra; 1994. p. 1-44.

6. Katz S, Mc Donald JL, Stookey GK. Preventive Dentistry in action. 3. ed. Buenos Aires: Med. Panamericana; 1982. p. 195-214.

7. Gómez S. Fluorterapia in dentistry. For the child and the adult. 3. ed. Santiago: Grant Educacional Colgate; 2001 . p. 183-98.

8. Echeverría S, Soto D, Zillmann G. Of nursing caries in children from 2 to 4 years in the Metropolitan Region. Diagnosis update. Rev Dent de Chile 2003; 1:15-9.

9. Chile. Ministerio de Salud. Acevedo C, Corsini G, Jans A. Diagnosis of buccal health of children of 2 and 4 years, that attend the prescholastic education in the Metropolitan Region. Chilean Health Ministry; 2007.

10. World Health Organization. Oral health surveys: basic methods. 4. ed. Geneva; 1997.

11. Chile. Ministerio de Salud. Urbina T, Caro J, Vicent M. Caries and dental fluorosis in children from 6 to 8 and 12 years of the II, VI, VIII, IX, X and MR. 1996. Chilean Health Ministry. Health Programs Division. Dental Department; 1996.

12. Chile. Ministerio de Salud. Yévenes I. Study: impact of fluoridation of drinking water in the metropolitan area, 2004-2005. Chilean Health Ministry; 2006.

13. Guerrero S, et al. Prevalence of maloclussions, fluorosis and caries in children's area of the South metropolitan region. Rev Dent Chile 1997;88:4-9.

14. Weason C, Garrido V, Mendoza E, Giuliano C Barboza P, Araya C. The oral health status in preschoolers in an urban school,
Concepción, Chile. XVIII Annual Meeting IADR Chile section. 2005; p. 49.

15. Yevenes I, Bustos BC, Ramos AA, Espinoza RM, Jara MN, PetrasicSmith L. Prevalence of dental caries in preschool children in Peñaflor, Santiago, Chile. Rev Odont Cienc 2009;24:116-9.

16. Brasil. Ministério da Saúde. Projeto SB: Condições de Saúde Bucal da População Brasileira 2002 -2003. Resultados Principias. Brasília (FD); 2004.

17. Paredes SO, Almeida DB, Fernandes JM, Forte FD, Sampaio FC. Behavioral and social factors related to dental caries in 3 to 13 year-old children from João Pessoa, Paraíba, Brazil. Rev Odont Cienc 2009;24:231-5.

18. Colombia. Ministry of Health. Special Report III: National Oral Health Survey - III Ensab Taken From SIVIGILA. Executive Weekly Report $N^{\circ} 8$ of 2000 Bureau of Epidemiology.

19. Maldonado de Yankilevich E et al. Distribution of dental caries in preschool children in an urban region, Argentina, 1992. Rev Saude Publica [serial on the Internet]. 1993 [cited 2008 Marc 28] ;27:43644. Available from: http://www.scielo.br/scielo. php? script=sci artt ext\&pid $=$ S003489101993000600006\&lng $=$ es\&nrm $=$ iso $>$. ISSN 0034-8910. doi: 10.1590/S0034-89101993000600006.

20. Pitts NB, Boyles J, Nugent ZJ, Thomas N, Pine CM. The dental caries experience of 5-year-old children in Great Britain (2005/6). Surveys co-ordinbated by The British Association for the study of community dentistry. Community Dent Health 2007;24:59-63.

21. Preschool Oral Health Survey in Spain 2007. RCOE 2007;12: 143-68.

22. Gillcrist JA, Brumley DE, Blackford JU. Community Fluoridation Status and Caries Experience in Children. J Public Health Dent $2001 ; 61: 168-71$.

23. Montero $\mathrm{M}$ et al. Experience of caries and dental fluorosis in school children consuming water with different concentrations of fluoride in Maiquetía, Vargas State, Venezuela. Invest. 2007 [cited 2008 Apr 2];48. Avalilable at: <http://www.scielo.org.ve/scielo. php? script =sci arttext\&pid=S0535-51332007000100002\& lng = pt\&nrm =iso $>$. ISSN 0535-5133.

24. Ortega-Maldonado M, Mota-Sanhua V, López-Vivanco JC. Oral Health Status of Adolescents in Mexico City. Rev Salud Publica (Bogotá) 2007;9:380-7. 